\title{
Высокоскоростной фотоприемный модуль на основе InAlAs/InGaAs/InP pin-диода с частично обедненным слоем для оптоволоконных систем передачи данных
}

\author{
К.С. Журавлев ${ }^{1}$, И.Б. Чистохин ${ }^{1}$, Н.А. Валишева ${ }^{1}$, А.М. Гилинский ${ }^{1}$, Д.В. Дмитриев ${ }^{1}$, В.С. Арыков ${ }^{2}$, \\ И.В. Юнусов ${ }^{2}$ \\ ${ }^{1}$ Институт физики полупроводников им. А.В. Ржанова, Новосибирск, \\ 630090, Пр. Академика Лаврентьева, 13 \\ ${ }^{2}$ ООО «Ай Эм Тех», Томск, 634041, Пр. Кирова, 51а, строение 5 \\ тел: +7 (383) 330-4475, эл. nочта: zhur@isp.nsc.ru
}

DOI 10.34077/RCSP2021-138

Задачи передачи аналоговых СВЧ-сигналов по волоконным линиям требуют использования высокоскоростных фотоприемников с эквивалентной чувствительностью 5-10 A/Вт и выше и низким напряжением питания. В работе рассматриваются конструкция и характеристики фотоприемного модуля для оптоволоконных систем передачи данных и СВЧ-сигналов, выполненного на основе скоростного pin-фотодиода и трансимпедансного усилителя для диапазонов частот до 2,5-10 ГГц. Скоростной ріn-фотодиод с частично обедненным поглощающим слоем выполнен на основе InAlAs/InGaAs/InP гетероструктуры и обеспечивает поглощение излучения в диапазоне длин волн 1,0 1,65 мкм. Использование в таких приборах частично обедненного поглощающего слоя позволяет увеличить граничную частоту за счет минимизации влияния пространственного заряда. Конструкция pin-фотодиода представляет собой меза-структуру круглого сечения с диаметром фотоприёмной площадки 20-40 мкм в зависимости от требуемого диапазона частот, имеющую прямоугольные $\mathrm{Au}$ балочные выводы толщиной 5 мкм. Подача излучения производится со стороны утоненной подложки гетероструктуры. Эпитаксиальная гетероструктура, выращенная методом молекулярно-лучевой эпитаксии на подложке полуизолирующего InP, содержит следующие слои:

- контактный $n^{+}$-InAlAs слой толщиной 300 нм с концентрацией легирующей примеси $5 \cdot 10^{18} \mathrm{~cm}^{-3}$,

- поглощающий $n^{+}$-InGaAs слой толщиной 50 нм с концентрацией легирующей примеси $5 \cdot 10^{18} \mathrm{~cm}^{-3}$

- нелегированный поглощающий $i$-InGaAs слой толщиной 220-800 нм (концентрация остаточной донорной примеси менее $\left.10^{15} \mathrm{~cm}^{-3}\right)$,

- легированный поглощающий $p^{+}-\mathrm{InGaAs}$ слой толщиной 100-220 нм с концентрацией легирующей примеси $1 \cdot 10^{18} \mathrm{~cm}^{-3}$,

- легированный широкозонный $p^{+}$-InAlAs слой толщиной 300 нм с концентрацией легирующей примеси $5 \cdot 10^{18} \mathrm{~cm}^{-3}$,

- контактный $p^{+}$-InGaAs слой толщиной 30 нм с концентрацией легирующей примеси $2 \cdot 10^{19} \mathrm{~cm}^{-3}$.

Усиление выходного сигнала фотодиода обеспечивает малошумящий бескорпусной трансимпедансный усилитель разработки АО НПЦ «Элвис». Усилитель обеспечивает возможность использования как несимметричной, так и симметричной линии передачи выходного сигнала. Чип усилителя монтируется совместно с чипом фотодиода в корпусе типоразмера TO-8. Подача излучения на фотодетектор возможна через оптоволокно либо через открытое пространство. 